\title{
Development of A Web based GIS Waste Disposal Management System for Nigeria
}

\author{
Adebayo P. Idowu, Emmanuel R. Adagunodo, Olapeju A. Esimai, \& Tosin C. Olapade \\ Department of Computer Science \& Engineering, Obafemi Awolowo University, Ile-Ife, Nigeria \\ Department of Community Health, Obafemi Awolowo University, Ile-Ife, Nigeria \\ paidowu@oauife.edu.ng
}

\begin{abstract}
Waste management has to do with handling of solid refuse from their sources of generation through storage, collection, transportation, recovery and treatment processes to disposal This research developed a web based GIS waste disposal management system, with aim of achieving an effective waste management system and a spatial view of waste collection locations in any local government area in Nigeria. The system was developed using Extensive Hypertext Markup Language and Cascading Style Sheet (XHTML/CSS), and Asynchronous Java Scripting with XML (AJAX) and the software packages used for the development of the application are Adobe Dreamweaver and Adobe Fireworks, MySQL, Apache Server and PHP scripting. With this waste management system, the locations of all the waste collection tanks in any location will be, monitored, managed and maintained. The use of this system will ease the job of the waste management unit of the local government areas in Nigeria in achieving a clean environment and mitigate the spread of epidemic in a way to ensure safety of all and sundry.
\end{abstract}

Index Terms-Solid waste, waste disposal, GIS, management system

\section{INTRODUCTION}

Solid waste management has to do with handling of solid refuse from their sources of generation through storage, collection, transportation, recovery and treatment processes to disposal ${ }^{[1]}$. Solid waste which is one of the sources and causes of environmental pollution has been defined under Resource Conservation and Recovery Act as any solid, semi-solid liquid or contained gaseous materials discarded from industrial, commercial, mining or agricultural operations and from community activities ${ }^{[2]}$. Solid waste also includes garbage, construction debris, commercial refuse, and sludge from water or waste treatment plants or air pollution, control facilities and other discarded materials ${ }^{[3]}$.

Thousands of lives are lost every year to environmental-related diseases such as cholera, diarrhea, malaria fever, typhoid fever, river blindness and so on.
Majority of people live in filthy, cockroaches, rats and mosquitoes-infected environment. The air, which is an unavoidable source of life, has been polluted with. chemicals, pathogens or offensive odour. Seepage from refuse dumps often pollutes the underground water and surface water. The environment is "sick" and the sickness is less than natural but the effect of human activities.

In order to protect human health and the environment from the potential hazards of inappropriate waste disposal and environmental pollution a systematically supervised and controlled handling of these wastes is a must. The type of wastes which constitute environmental pollution which this work concentrates on is domestic refuse consisting of degradable food wastes, leaves, dead animals and non-degradable ones such as plastics, bottles nylon, medical and hospital wastes, generated in households, hospitals, industries and commercial centers [4].

Waste is a continually growing problem at global and local levels. Solid wastes arise from human and animal activities that are normally discarded as useless or unwanted. In other words, solid wastes may be defined as the organic and inorganic waste materials produced by various activities of the society and which have lost their value to the first user ${ }^{[5]}$.

As the result of rapid increase in production and consumption, urban society rejects and generates solid material regularly which leads to considerable increase in the volume of waste generated from several sources such as, domestic wastes, commercial wastes, institutional wastes and industrial wastes of most diverse categories ${ }^{[2]}$ Management of solid waste may be defined as that discipline associated with the control of generation, storage, collection, transfer and transport, processing, and disposal of solid wastes in a manner that is in accord with the best principles of public health, economics, engineering, conservation, aesthetics, and other environmental considerations ${ }^{[5]}$.

In its scope, solid waste management includes all administrative, financial, legal, planning, and engineering functions involved in the whole spectrum of solutions to problems of solid wastes thrust upon the community by its inhabitants ${ }^{[5]}$. Solid wastes have the 
potential to pollute all the vital components of living environment (i.e., air, land and water) at local and at global levels. The problem is compounded by trends in consumption and production patterns and by continuing urbanization of the world. The problem is more acute in developing nations than in developed nations as the economic growth as well as urbanization is more rapid ${ }^{[5]}$.

Waste as it is construed in today Nigeria is anything that lacks utility or object or substance that the owner either voluntarily or involuntarily relinquishes ownership of. It is a potential hazard by virtue of its nature and composition and so its management is a hazardous activity. A clean and serene environment is very important tool for achieving a good health.

Ethically, the beauty of any environment lies on its good sanitary condition. This is so because, when an environment is clean the lives of citizenry are not threatened by illness and diseases. Proper refuse disposal management involves the dumping of waste (solid, liquid or gaseous) from our homes, industries and public outfits for example hotels, hospitals, homes and schools etc at a specific place or in government provided containers, the control and removal of refuse from places where they can cause hazards to a place where they are less hazardous to public health.

In order to manage solid waste efficiently and effectively in any community in Nigeria, there is the need for a reliable national waste management database and a national waste management system, this research developed a web-based solid waste management system. The system would be used in the management and controlling of solid waste, which would eventually reduce or eliminate health problems that is associated with solid waste in Nigeria.

\section{WASTE MANAGEMENT SYSTEM}

Waste (also.known.as rubbish, trash, refuse, garbage, $\mathrm{j}$ unk, and litter) is unwanted or useless materials ${ }^{[6]}$. Waste as the name "sound" is an unwanted and unprofitable materials and attract less attention from the community and that is why there is no much work in the area software development aimed or targeted to improve the work of society or organizations set up for its management. It is understandable that other sector like Finance, Health, Agriculture, Technology, Manufacturing, Education etc. has lot of effort in the area of software development committed to their effectiveness and service improvements.

Waste is directly linked to human development, both technological and social. The compositions of different wastes have varied over time and location, with industrial development and innovation being directly linked to waste materials. Examples of this include plastics and nuclear technology. Some waste components have economic value and can be recycled once correctly recovered. Waste is sometimes a subjective concept, because items that some people discard may have value to others. It is widely recognized that waste materials can be a valuable resource, whilst there is debate as to how this value is best realized. Such concepts are colloquially expressed in western culture by such idioms as One man's trash is another man's treasure ${ }^{[7]}$.

Wastes are materials that are not prime products (that is products produced for the market) for which the generator has no further use in terms of his/her own purposes of production, transformation or consumption, and of which he/she wants to dispose. Wastes may be generated during the extraction of raw materials, the processing of raw materials into intermediate and final products, the consumption of final products, and other human activities. Residuals recycled or reused at the place of generation are excluded ${ }^{[8]}$.

In the other hand, Sanitary Landfill - is a fully engineered disposal option, which avoids harmful effects of uncontrolled dumping by spreading, compacting and covering the wasteland that has been carefully engineered before use. The four minimum requirements for setting up a sanitary landfill are full or partial hydrological isolation, formal engineering preparation, permanent control and planned waste placement and covering. Land filling relies on containment rather than treatment (for control) of wastes. Appropriate liners for protection of the groundwater, leachate collection and treatment, monitoring wells and appropriate final cover design are integral components of an environmentally sound sanitary landfill ${ }^{[9]}$.

Waste management is the collection, transport, processing (waste treatment), recycling or disposal of waste materials, usually ones produced by human activity, in an effort to reduce their effect on human health or local aesthetics or amenity. It can involve solid, liquid or gaseous substances with different methods and fields of expertise for each ${ }^{[10]}$

Waste management for non-hazardous residential and institutional waste in metropolitan areas is usually the responsibility of local government authorities, while management for non-hazardous commercial and industrial waste is usually the responsibility of the generator $^{[11]}$.

Many method of waste reduction had evolve over the years and the way they are been done varies from one country to another and also with respect to the type waste generated as well as the countries productivity strength. The 3-R method of waste control is an example

i. reduce - reduce the amount of waste generated

ii. reuse - making by product of particular processes reusable

iii. recycle - and also recycling the abandoned part to produce new equipments.

The aim of the 3-R method of waste management is to extract the maximum practical benefits from all generated waste products and so have to bother with minimum amount ${ }^{[12]}$.

Waste Management software (WMS) can be a powerful tool for any business seeking to monitor its environmental impact and maximize profit by curbing needless waste and managing risk. In most jurisdictions, 
some form of environmental performance is mandated by local, regional, state, provincial and federal legislation. A WMS is the best way to ensure compliance with all relevant legislation. It is not essential to use a software-based platform to have a fulsome WMS, results continually show environment management software is the most effective and efficient means of implementing and maintaining a robust WMS as well as ensuring continued compliance with regulatory and legislative standards.

In Nigeria the only system that has just been launched is an automated web-based Early Warning System (EWS), which could be used in dealing with the destructive effects of persistent flooding in the country and this was launched in Lagos in the year 2011. This is an effort to combat the adverse effect of climate change for sustainable development, food security, and the well being of the people. The major weakness of this system is its inability to show a spatial view of the waste collection sites and the appropriate collection time, to prevent overflow and blocking of drainages which results in flooding.

An electronic, centralized system for the management of all waste-related information will carry significant benefits for any organization, including:

- Cost and efficiency savings through the streamlined collection, assessment and reporting of data.

- Streamlined environment management processes and the elimination of duplicate data.

- Real-time access corporate environment performance metrics.

- Risk mitigation through the tracking and automatic following-up on corrective actions [13].

\subsection{Waste Management in Developed nations}

Solid waste consists of everyday items that could be thrown away or recycled such as bottles, cans, newspapers, computers, furniture, food, and appliances ${ }^{[14]}$. From the early days of civilization, humans have used the earth's resources and disposed of wastes. In ancient times, waste disposal did not pose a significant problem, for the population was small and land available to receive waste materials was abundant. Waste related problems commenced to occur from the time when humans began to congregate in larger communities. The medieval practice of throwing waste into the unpaved streets, combined with a lack of proper handling of faeces, led to a fast breeding of rats carrying fleas which acted as vectors for the bubonic plague: As a consequence, half of the European population was erased in the fourteenth century.

First regulations regarding proper waste collection in Europe date back to the 18th century. Technical standards became implemented in all major cities during the industrial revolution. Recovery - at a significant scale and in an organized way - of waste components suitable for animal feed and further industrial processing (glass, metals, paper, textiles) also dates back to the 18th century and can be found today throughout Europe at all levels ${ }^{[15]}$.

One of the most obvious impacts of rapidly increasing urbanization and economic development can be witnessed in the form of heaps of municipal solid waste. Based on estimates, waste generation in Asia has reached 1 million tons per day. A World Bank study showed that urban areas in Asia spent USD25 million per year on solid-waste management, and this figure will increase to USD47 million per year. Despite the huge expenditures, urban areas in most Asian Productivity Organization (APO) member countries are still grappling with the challenge of preventing environmental degradation due to nonsystematic solid-waste management.

Apart from the contamination of water resources and severe air pollution due to the open burning of solid waste, the health hazard is another key issue to be addressed. Solid-waste management has become an important issue in the Asia-Pacific region, and it needs to be resolved through an integrated community, private sector, and policy-based approach. Since recognizing the significance of solid-waste management, the APO has been organizing multi-country workshops, seminars, and conferences to discuss related issues and problems in member countries and devise solutions.

A survey was conducted on solid-waste management in 11 APO member countries: Bangladesh, Republic of China, India, Islamic Republic of Iran, Malaysia, Nepal, Philippines, Singapore, Sri Lanka, Thailand, and Vietnam to assess current solid-waste management practices and to highlight issues, problems, and the initiatives undertaken to tackle them. This survey was also an attempt to create a consolidated database on solid waste that can be utilized for planning purposes at the national level and for strategy formulation for regional planning ${ }^{[16]}$.

\subsection{Waste Management System in Nigeria}

The management of municipal solid waste has become an acute problem due to enhance economic activities and rapid urbanization. Increased attention has been given by the government in recent years to handle this problem in a safe and hygienic manner ${ }^{[17]}$. According to Solomon (2009), it is estimated that an average person generates about $0.49 \mathrm{~kg}$ of solid waste per day with households and commercial centers contributing almost $90 \%$ of total urban waste burden. Little information exists on industrial, agricultural and biomedical waste profiles ${ }^{[18]}$. As with most developing countries, a greater percentage of solid waste composed of organic matter, but recently there has been a marked increased in the amount of plastic and electronic wastes generated in recent times.

In this regard, Municipal Solid Waste Management (MSWM) environmental audit has been carried out for different communities through the collection of secondary data from the government agencies, and interviewing stake holders and field surveys. Field survey was carried out in different parts to understand 
the practice and the lacuna ${ }^{[19]}$. Research work carried out to understand the efficacy and shortfalls, shows that, $35 \%$ of the bins are covered while evaluating the storage options. $24 \%$ of the area has community bins and $90 \%$ of the residential areas have adopted a door-to-door method for the collection of waste. Recycling carried out mainly by the informal sector (rag pickers) has high level of efficiency and the recyclables are being retrieved by this sector at all stages starting from collection to disposal of wastes at dump sites ${ }^{[20]}$.

A study in Nigeria showed that municipal solid wastes are produced in the urban areas at a mean rate of 0.43 $\mathrm{kg} / \mathrm{head} /$ day. This is evident as it is not uncommon going through the length and breadth of the country (Nigeria) to find heaps of refuse littering the entire landscape, road sides and commercial centres, even on the premises of primary, secondary and tertiary institutions as a result of improper management strategies ${ }^{[21]}$.

The reason for this is not far fetch, software developers develop applications for profit reasons, and the sector listed above has enough capital based and policy support to acquire any software application that can improve their service. The management of municipal solid waste has become an acute problem due to enhance economic activities and rapid urbanization. Increased attention has been given by the government in recent years to handle this problem in a safe and hygienic manner ${ }^{[17]}$.

According to Solomon (2009), it is estimated that an average Nigerian generates about $0.49 \mathrm{~kg}$ of solid waste per day with households and commercial centers contributing almost $90 \%$ of total urban waste burden. Little information exists on industrial, agricultural and biomedical waste profiles ${ }^{[18]}$. As with most developing countries, a greater percentage of solid waste composed of organic matter, but recently there has been a marked increased in the amount of plastic wastes generated in Nigeria.

\subsection{Existing Waste Management Systems}

Troschinetz, (2005) identified twelve factors influencing sustainable recycling in developing countries, while considering the three dimensions of sustainable environment, society, and economy. The factors were derived from quantitative and qualitative examination of twenty-three case studies of developing countries ${ }^{[23]}$.

Jennifer, (2005) conducted a feasibility study and comprehensive action plan for a large scale municipal composting operation at the Riverton disposal site in Kingston, Nigeria ${ }^{[24]}$. The rationale for this study came from the desire of the Government of Nigeria to integrate waste reduction strategies into the existing solid waste management (SWM) system in order to divert compostable waste from the landfill. The operation was designed to process commercial organic waste, not household organics. The use of appropriate technology for the composting operation was emphasized by ${ }^{[24]}$, which the author states is often overlooked in developing countries that import high-tech equipment and designs from aid agencies and developed countries. The author discusses the three main categories of composting technologies: window composting, aerated static piles, and in-vessel composting.

Economic benefit was the primary goal of this composting operation, since the quantities of organic waste originating from the planned sources did not represent significant waste reduction. Significant to the present research, ${ }^{[25]}$ suggested that significant waste reduction could be accomplished through source reduction with increased backyard composting, since about $50 \%$ of household waste is organic material.

The above studies just examined provide a foundation for further investigation into the feasibility of waste reduction strategies in developing countries. In the study [25] concluded that large-scale composting was economically feasible, but suggested that backyard composting and source reduction would result in greater quantities of diverted waste. Table 1 gives the summary of the existing waste management systems

Table 1. Summary of Existing Waste Management Systems

\begin{tabular}{|c|c|c|c|}
\hline $\begin{array}{c}\text { Author \& } \\
\text { Year }\end{array}$ & Scope & Strength & Limitation \\
\hline $\begin{array}{l}\text { Pendley, } \\
\text { (2005) }\end{array}$ & $\begin{array}{l}\text { Composting } \\
\text { Operation } \\
\text { Technology at } \\
\text { Riverton Disposal } \\
\text { Site, Kingston, } \\
\text { Jamaica }\end{array}$ & $\begin{array}{l}\text { deals } \\
\text { composting } \\
\text { technology used } \\
\text { for wealth } \\
\text { creation in } \\
\text { agriculture }\end{array}$ & $\begin{array}{l}\text { not web } \\
\text { based GIS } \\
\text { based. }\end{array}$ \\
\hline $\begin{array}{l}\text { Troschinz } \\
\text { (2005) }\end{array}$ & $\begin{array}{l}\text { Sustainable } \\
\text { Recycling of } \\
\text { Municipal Solid } \\
\text { Waste }\end{array}$ & $\begin{array}{l}\text { identified cheap } \\
\text { source of raw } \\
\text { materials via } \\
\text { recycling and }\end{array}$ & $\begin{array}{l}\text { not web } \\
\text { based GIS } \\
\text { based. }\end{array}$ \\
\hline $\begin{array}{l}\text { Jennifer L. } \\
\text { (2007) }\end{array}$ & $\begin{array}{l}\text { Solid Waste } \\
\text { Management }\end{array}$ & $\begin{array}{l}\text { identifies solid } \\
\text { waste and their } \\
\text { management. }\end{array}$ & $\begin{array}{l}\text { not web } \\
\text { based GIS } \\
\text { based. }\end{array}$ \\
\hline
\end{tabular}

\section{METHOD}

According to Solomon (2009), it is estimated that an average Nigerian generates about $0.49 \mathrm{~kg}$ of solid waste per day with households and commercial centers contributing almost $90 \%$ of total urban waste burden. As with most developing countries, a greater percentage of solid waste composed of organic matter, but recently there has been a marked increased in the amount of plastic wastes generated in Nigeria ${ }^{[18]}$.

Data for the project were collected mainly through direct observation. The population and the spread of population were the major factors considered for the sitting of the waste tanks, collection bins and 
The researchers moved round the some cities in Nigeria, to examine the way and manner the waste collection tanks were set out, and also the activity hit rate on each of them to suggest the type and number needed to serve a particular section of the campus at the optimum.

There are several tools or programming languages that could be employ for the development or design of a system but the choice of the programming language and tools used depend greatly on so many factors or conditions e.g. flexibility, goals of the system, ease of use, ease of understanding, targeted end users, size of the industry for which the system was proposed and lots more. The coding of this system was done using the, macromedia suite (macromedia fireworks, dreamweaver, flash), object oriented PHP, MySQL, XML, Java script and Apache. These tools were chosen because of their level of integration, use of use and suitable Graphical User Interface (GUI) that makes the use of system easy to understand and manage.

\section{SYSTEM ARCHITECTURE}

The Solid Waste Disposal Management System (SWMS) supports a database, business logic, and the user interface as the major areas of its design. The user machine is the device use in accessing the pages and forms use for the web application e.g phones, laptops etc. and the local host is the program that launches the application and makes it behave as if it is actually hosted on the internet, the back-end is the web server and database management system engine that manages the data use by the application and the PHP script controls the movement of data between the user front-end and the application back-end. System architecture diagram is as shown in figure 1.

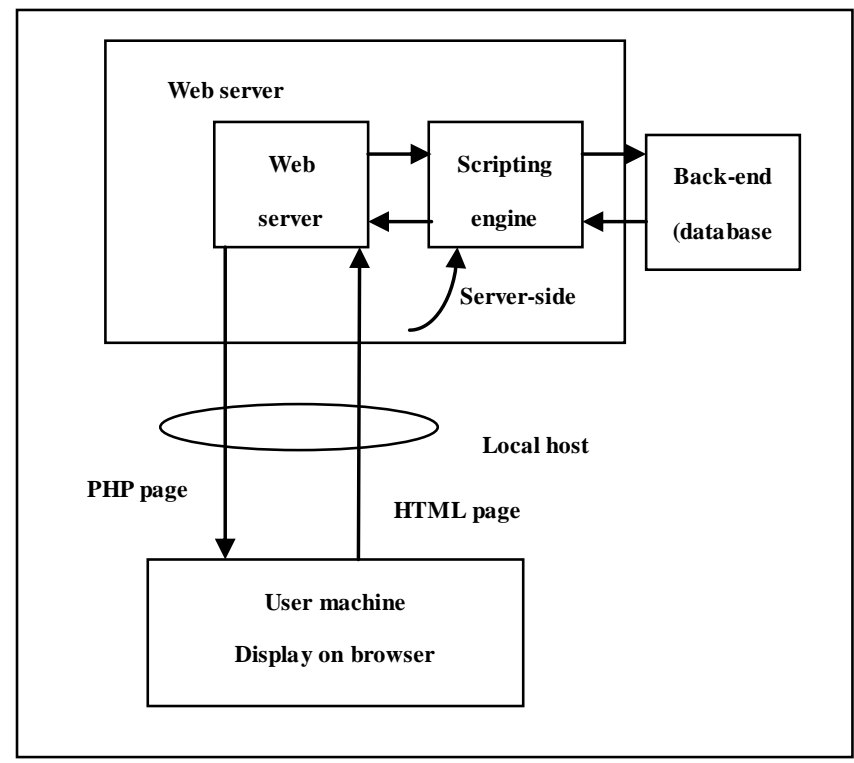

Figure 1. System architecture

V. USED CASE DIAGRAM FOR SWMS
The use case diagram is used in presenting the system requirements of any proposed system. A use case is a realistic description of the workflow of the system and it is used to explicitly describe the intentions and actions of users ${ }^{[26]}$. The use case diagram, which present the system requirements are used to show how the proposed system work in practice. The interaction between actor and use cases are also described using use case diagram. The use case diagrams of the solid waste management system are as presented in figure 2 below.

The use case diagrams show how data will be entered and viewed from the solid waste management system. The staff of the local government would be able to enter all required data of the entire streets in the specified location into the information system or national database.

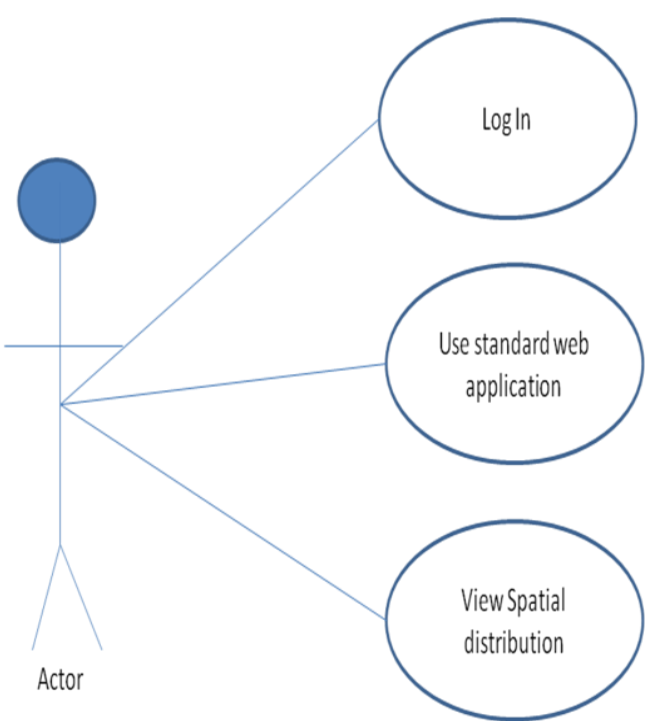

Figure 2: Use case diagram for the system

\section{IMPLEMENTATION OF THE SWMS}

\subsection{User Interface Design}

The user interface allows the user to navigate the system and communicate with the database. The system design is simple enough to be use for anyone with little knowledge of computer operation, so that the system overall objectives can be achieved. The system is user friendly and made easy to use through the use of Windows, Interface Menu and Pointing devices (WIMP) which is very important in computer graphics design and architecture. In addition to the spatial addresses provided in the map of the solid waste collection sites, a pictures of each of the waste collection container sites is provided at a single click of the location on the map so the user of the map or the system is sure of the location being reported to the environmental management staff and also 
that the right and responsible staff for the location is being called upon, as the information of staff attached to each of the collection sites is provided on the pages.

The Waste Management System was design to accommodate users of varying skills and competence in the area of computer usage, so with the employment of the WIMP paradigm via the use of pointing devices and graphical icons that represent the specific task that the user wanted to perform makes the system usage easy and convenient for all. A well design user interface provide user with better understanding of a system and some part of the system are captured and explain in the figure 3 below.

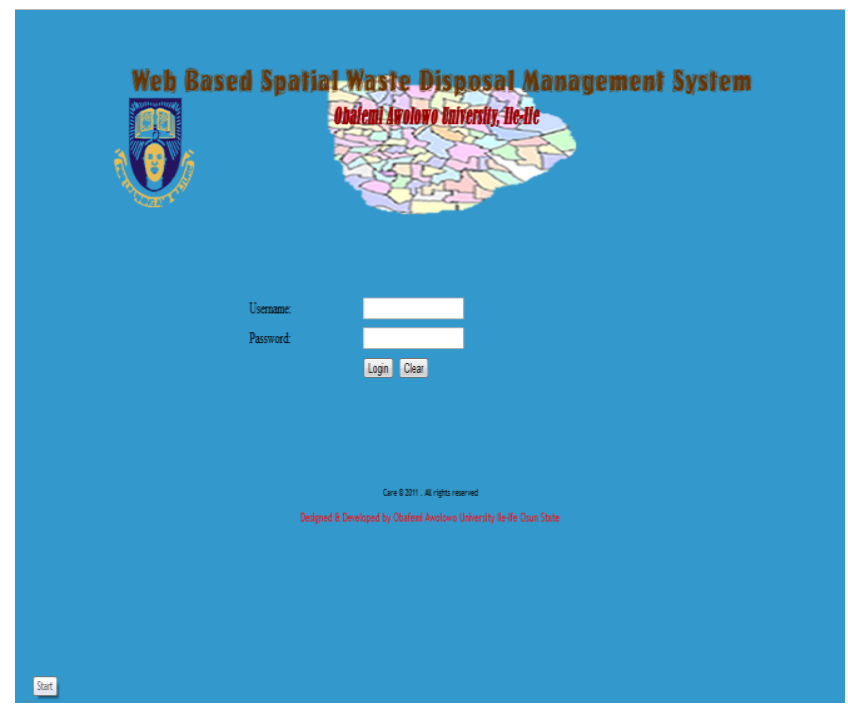

Figure 3. The user interface of the SWMS.

\subsection{Application Panel}

The application panel page allows users to use the different functionality the system provides, easy understanding and navigation of the new system. All parts of the application can be access from this page, the icons used in the design depicts the operations each of the items on the page performs. It is an application of the WIMP paradigm or standard. The menu allows a new collection point to be defined and added to the site table of the already existing sites. Delete site icon makes deletion of an existing site possible when it is no longer in use or unavailable. New Staff makes the addition of new staff possible and all staff attribute and role clearly define for easy administrative control and this is depicted in figure 4.

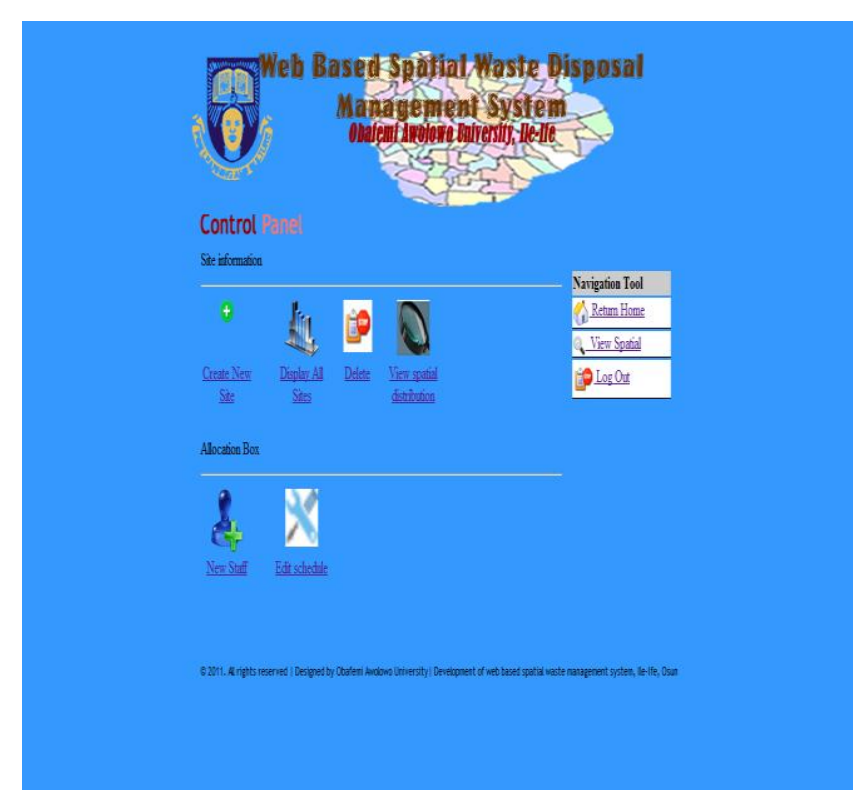

Figure 4: Application Panel

\subsection{Spatial Distribution of Waste Bins}

The spatial distribution of waste bins provides the geographical information of all the waste collection tank in any ward. Clicking each of the points in the map gives a spatial view of the location or site clicked on map and a brief description of the site. It is a valuable tool to easy navigation, control, administrative and spatial view of all collection site that can be found within the specified location as shown in figure 5 .

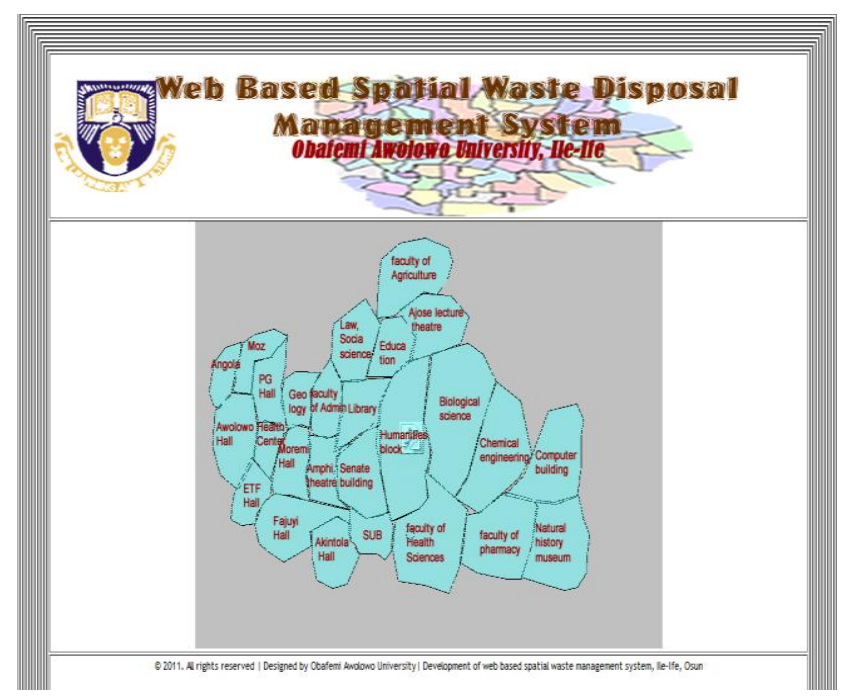

Figure 5. Spatial Distribution of Waste Bin

\subsection{Site input form}

The site input forms are designed to capture data from both the users and administrators of the systems, new site data entry form takes information of newly defined sites, makes the definition and creation of newly positioned collection site possible. The menu captures data about 
a new collection site and detailed address of the site to inform the user and the staff assigned to them for proper usage and better control as shown in figure 6 .

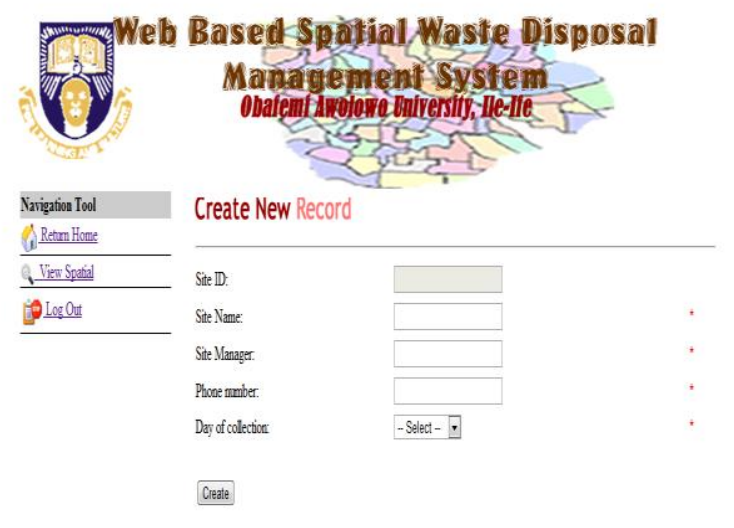

Figure 6: Site Input Form

\subsection{View Site Schedule}

This displays the schedule of staff, supervisors and the sites they are responsible to service around any location. The schedule provides information about the people and users of the system through this can call or send an sms to the person or team assign the task of evacuation of a site that requires attention before it overflows and been washed into the drainages, or for other reasons. As shown in figure 7.

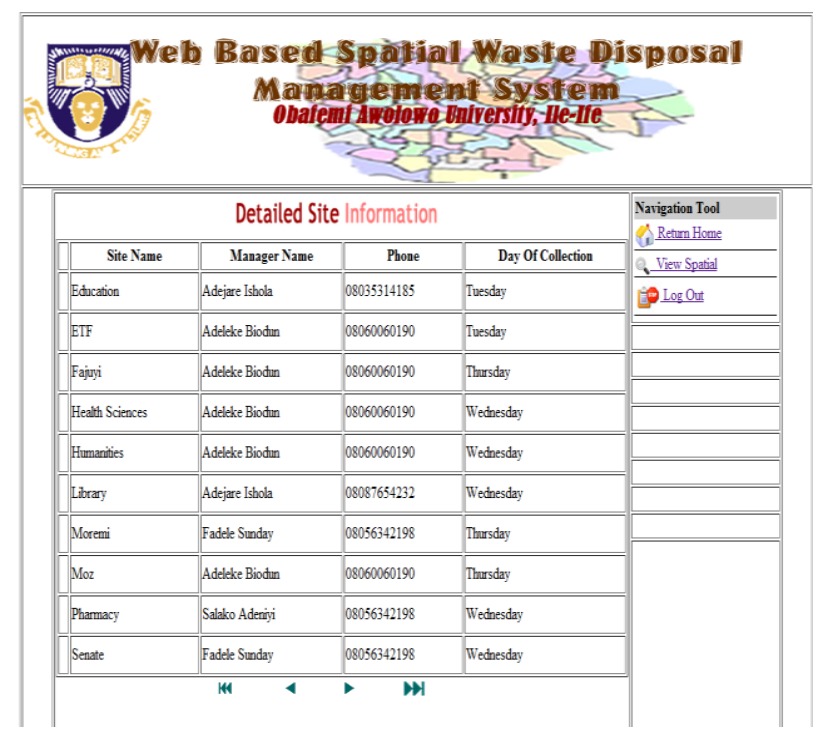

Figure 7: View Site Schedule

\section{DISCUSSION}

With the waste disposal management system, the health officers would be able to type in the details information about their work on waste disposal time and day they are to visit any location so as to collect their refuse. Also, the public would be able to know days of the weeks, the refuse collector will be coming to their area so as to collect refuse. The supervisor in the office can assess the work done by the subordinate before the arrival to the office. In addition, all the information can serve as a guide for the health policy maker to make useful decision. This system demonstrates that web based system may enhance waste disposal management system in two ways. One is to enhance tracking data management and this is achieved by editing, reporting, deleting refuse data. The other is to enhance tracking information services, such as the provision of a query, generation of reports, among others.

\section{CONCLUSIONS}

In conclusion, this research presents a solid waste management system for Nigeria. The SWMS developed is not a complex system because the SWMS was developed to allow public to be able to view the time and day in which refuse will be collected in any location. It also aid the health workers to be able to key in details information of the work carried out on daily basis while on the field and immediately the information is being stored into the management system, other stakeholders can work on the information, make useful decision. Also, the policy makers and other stakeholders can view any refuse collection of any location real-time.

This research work emphasizes the effective and efficient ways of monitoring environmental waste, in such a manner that guarantee healthy living and disease free society resulting from improper management of solid or organic waste from their sources. The solid waste management system provides a spatial view of the waste collection tanks. It provides detail information about refuse for easy reporting and administrative control of solid waste; prevent overflow and eventual blocking of drainages.

The use of the waste management system will help in mitigating the effect and risk that are mostly experience as a result of careless handling of these waste and the collection sites. It will also aid the prompt delivery of the services of the environmental unit of the local government areas in Nigeria.

\section{REFERENCES}

[1] Tchnobanoglous, G., Kreith, F. (2002). "Handbook of Solid Waste Management", 2nd edition, McGraw-Hill Handbooks. 
[2] Omoleke, I.I, (2004); "Management of Environmental Pollution in Ibadan, An African City: The Challenges of Health Hazard Facing Government and The People”, J. Hum. Ecol., 15(4):pp 265-275

[3] Ajibade, L. T. et al. (2005): "Quality Evaluation of Packed for Human Consumption in Ilorin, Kwara State": Proc. Nat. Conf., University of Ilorin.

[4] Tchobanaglous, G., Theisen, H., and Eliassen, R., (1997). "Solid wastes: Engineering principles and management issues". McGraw Hill publications, New York, USA.

[5] Opara, J.A (2008)."Urban Waste Control and Management: Issues and Challenges". Journal of Environmental Management and Education, 1(1), pp.1-61.

[6] Haghi, A.K., (2010) "Waste and Waste Management" Nova science pub inc.

[7] Diaz, L. et al (2006). "Solid Waste Management", Volume 2. UNEP/Earthprint,.

[8] Ray, A. "Waste management in developing Asia: Can trade and cooperation help?" The Journal of Environment \& Development 17.1 (2008): 3-25.

[9] Kumar, S., Mondal, A. N., Gaikwad, S. A., Devotta, S., and Singh, R. N. (2004). "Qualitative assessment of methane emission inventory from municipal solid waste disposal sites": a case study, Atmospheric environment 38, Issue 29, 4921- 4929.

[10] Kaila, J., (1987). "Mathematic Model for Strategic Evaluation of Municipal Solid Waste

management system", technical research centre of Finland Publication 40, Espoo. Finland.

[11] Tchobanoglous G, Theisen H, Vigil S (1993). "Integrated Solid Waste Management" - McGrow Hill Series, p. 7.

[12] Encyclopedia, 2009 edition.

[13] Bryden, W. and Paul, L (2010).: "Demystifying Environmental Management Software, Achieving Goals and Maximizing" ROI: Intelex Technologies Inc. 905 King Street W, Suite 600, Toronto, Canada.

[14] U.S. Environmental Protection Agency. (2009, February 18). Wastes - Resource conservation -

Reduce, reuse, recycle. In Reduce, reuse, recycle. http://www.epa.gov/osw/conserve/rrr/.

[15] Goodship, V. (2010). "Management, Recycling and Reuse of Waste Composites", CRC press,UK.

[16] Asian Productivity Organization (2007) "Survey on Solid-Waste Management " 2004-05 Edited by the Environmental Management Centre, Mumbai, India. Published by the Asian

Productivity Organization.

[17] Srivastava, A. K. (2003). "Environment Audit”, A. P. H Publishing Corporation, New Delhi.

[18] Solomon, U. U. (2009): "The State of Solid Waste Management in Nigeria". Wuhan, Hubei: Department of Environmental Engineering, Chin
University of Geosciences, Wuhan, Hubei.

[19] Haque, A. (1998). "Limits to plastic recycling in the developing and developed Economy".

Unpublished $\mathrm{PhD}$ thesis, Imperial College, London.

[20] Harashima, Y., (2000). "Environmental Governance in Selected Asian Countries". International Review for Environmental Strategies 1, no 1, 193-207.

[21] Onibokun, A.G.; Adedipe, N.O. and Sridhar, M.K.C. (2000): "Centre for African Settlement

Studies and Development". (CASSAD)

Monograph Series No. 13. Ibadan: CASSAD

Publication; pp 1-134.

[22] Srivastava, A. K. (2003). "Environment Audit”, A. P. H Publishing Corporation, New Delhi.

[23] Troschintez, A. (2005). "Twelve Factors Influencing Sustainable Recycling of Municipal Solid Waste in Developing Countries." Masters of Science in Environmental Engineering

Thesis, Michigan Technological University. Houghton, Michigan.

[24] Jennifer L. (2007) “ Solid Waste Management" Unpublished Msc thesis, Department of Civil,

Michigan Technological University, Houghton, Michigan.

[25] Pendley, P.S. (2005). "Feasibility and Action Plan for Composting Operation Incorporating

Appropriate Technology at Riverton Disposal Site, Kingston, Jamaica." Unpublished Msc thesis, Department of Environmental Engineering, Michigan Technological University. Houghton, Michigan.

[26] Jacobson, I., Cristerson, M., Jonsson, .,Övergaard, G. (1992) : Object Oriented Software Engineering: A Use Case Driven Approach. MA:Addison-Wesley

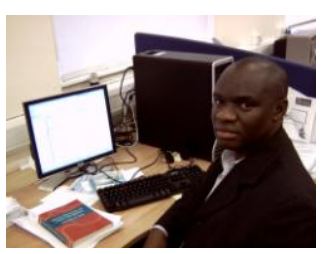

Adebayo P. Idowu: He is a Lecturer at the Obafemi Awolowo University, Nigeria. $\mathrm{He}$ is also a Member of British Computer Society and Nigerian Computer Society. He authored many journal articles in Nigeria and abroad. His research interests include Software Engineering, Geographical Information System, Database Design, and Health Informatics. He enjoys reading and driving.

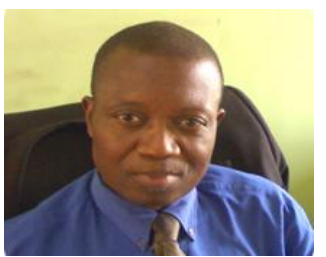

Emmauel R. Adagunodo: He is a Professor of Computer Science \& Engineering in Obafemi Awolowo University, Nigeria. He is presently Head of Computer Science \& Engineering, $\mathrm{He}$ is a Registered Member of Nigeria Computer Professional of Nigeria, and Nigerian Computer Society. He is an external 
examiner to many universities in Africa. He has supervised many Doctoral and Master Students. He is an author of many journal articles both within and abroad. His research interests include Software Engineering, and operating system.

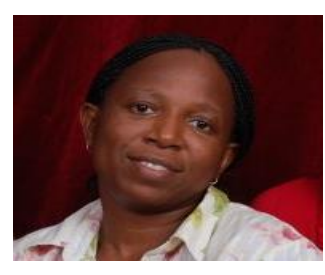

Olapeju A. Esimai: She is an Associate Professor /Consultant in Department of Community Health Obafemi Awolowo University, Nigeria. She lectures both undergraduates and postgraduates students in Departments of Community Health, Medical Rehabilitation and Nursing the area of Reproductive Health, Epidemiology and Environmental. She is actively involved in researches in the area of Reproductive Health and Environmental Health . Her research interest include Epidemiology, International and Environmental Health and Reproductive Health. She authored many journal articles within and outside Nigeria.

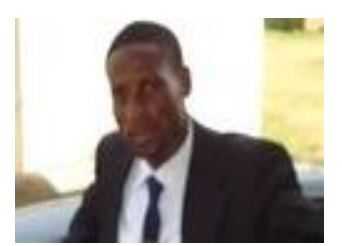

Tosin C. Olapade: He is a graduate of Department of Computer Science \& Engineering, Obafemi Awolowo University, Nigeria.

His research interest include software engineering and health informatics. 